\title{
Dominant shrub species are a strong predictor of plant species diversity along subalpine pasture-shrub transects
}

\author{
Tobias Zehnder $^{1,2} \cdot$ Andreas Lüscher $^{1}(1) \cdot$ Carmen Ritzmann $^{1} \cdot$ Caren M. Pauler $^{1}\left(\mathbb{D} \cdot\right.$ Joel Berard $^{3,4}(\mathbb{D})$ \\ Michael Kreuzer ${ }^{2}$ (I) - Manuel K. Schneider ${ }^{1}$ (])
}

Received: 15 February 2020 / Accepted: 31 August 2020 / Published online: 14 September 2020

(c) The Author(s) 2020

\begin{abstract}
Abandonment of pastures and successional shrub expansion are widespread in European mountain regions. Moderate shrub encroachment is perceived beneficial for plant diversity by adding new species without outcompeting existing ones, yet systematic evidence is missing. We surveyed vegetation along 24 transects from open pasture into shrubland across the Swiss Alps using a new protocol distinguishing different spatial scales, shrub cover of each plot $(2 \times 2 \mathrm{~m})$ and larger-scale zonal cover along the transect. Data were analysed using generalized linear models of shrub cover, shrub species and environmental conditions, such as geology, aspect or soil. Most shrub communities were dominated by Alnus viridis (62\% of transects) and Pinus mugo (25\%), and the rest by other shrub species (13\%). These dominant shrub species explained vegetation response to shrub cover well, without need of environmental variables in the model. Compared to open pasture, A. viridis resulted in an immediate linear decline in plant species richness and a marginal increase in beta-diversity (maximally $+10 \%$ at $35 \%$ cover). Dense A. viridis hosted 62\% less species than open pasture. In P. mugo, species richness remained stable until $40 \%$ shrub cover and dropped thereafter; beta-diversity peaked at 35\% cover. Hence, scattered $P$. mugo increases beta-diversity without impairing species richness. In transects dominated by other shrubs, species richness and beta-diversity peaked at $40-60 \%$ shrub cover (+23\% both). A. viridis reduced species richness in a larger area around the shrubs than P. mugo. Therefore, effects of shrub encroachment on plant diversity cannot be generalized and depend on dominant shrub species.
\end{abstract}

Keywords Biodiversity $\cdot$ Vegetation $\cdot$ Mountain $\cdot$ Succession $\cdot$ Shrub encroachment $\cdot$ Conservation

\section{Introduction}

Grasslands cover large areas in mountains worldwide (Dong et al. 2011). Many of them are created and modified over millenia by human activities, especially by forest clearance, mowing and grazing livestock in transhumance systems (Holtmeier 2009; Lauber et al. 2013). In the European Alps, forest established after the retrieval of glaciers around

Manuel K. Schneider

manuel.schneider@agroscope.admin.ch

1 Agroscope, Forage Production and Grassland Systems, Reckenholzstrasse 191, 8046 Zurich, Switzerland

2 Institute of Agricultural Sciences, ETH Zurich, Universitätstrasse 16, 8092 Zurich, Switzerland

3 Agroscope, Animal Production Systems, Rte de la Tioleyre 4, 1725 Posieux, Switzerland

4 ETH Zurich, AgroVet-Strickhof, Eschikon 27, 8315 Lindau, Switzerland
10,000 years ago, but was already modified by humans from around 6500 before present (Schwörer et al. 2015). Since then, vegetation has adapted to the regular disturbance exerted by selective defoliation and trampling of ruminants (Pauler et al. 2020). Depending on environmental conditions and management, diverse pasture communities have developed, thereby forming a cultural landscape (Ellenberg 1988). The establishment of pastoralism increased species richness but also reduced wood cover (Schwörer et al. 2015). In the Alps, this has lowered the treeline by up to $350 \mathrm{~m}$ : Open land was created in the subalpine zone, where in contrast to the alpine zone, trees would dominate naturally (Carnelli et al. 2004). Alpine and subalpine pastures range amongst the most biodiverse habitats worldwide (Wilson et al. 2012) and provide important services to society (Tasser et al. 2020).

Farming of mountain grassland has undergone considerable changes in recent decades (Lauber et al. 2013). Besides land use intensification on fertile land, land abandonment of remote areas is common (Queiroz et al. 2014; Tasser and 
Tappeiner 2002) and both these changes were found to have negative effects on plant species diversity (Peter et al. 2009; Strebel and Bühler 2015). Steep slopes not suitable for modern machinery, areas not developed with roads and zones of shallow soils tend to be given up (Gellrich and Zimmermann 2007). Abandonment is enforced by the shortage of labour due to increased employment outside the agricultural sector and by altered livestock production due to a shift from goats to sheep or from dairy to suckler beef cows (Liechti and Biber 2016). As a consequence, summer-grazed pastures in Switzerland have diminished by $295 \mathrm{~km}^{2}$ (equivalent to $5.4 \%$ of the total) between 1985 and 2009, primarily in the subalpine zone (BFS 2013).

The reduction or removal of grazing pressure in pasture ecosystems changes vegetation composition. Grazingresistant plant species lose their competitive advantage and decline relative to species which grow taller and invest more resources into persistent above-ground structures such as woody plants, tall herbs and grasses (Díaz et al. 2007). Not surprisingly, the above-mentioned changes in mountain farming are reflected in land cover. Between 1993 and 2006, shrubland in the Swiss Alps increased by more than $120 \mathrm{~km}^{2}(20 \%)$ and this type of vegetation represents one of the fastest expanding habitats in Switzerland (Brändli 2010). The Swiss National Forest Inventory (Brändli 2010) defines shrubland as vegetation, in which woody plants below $3 \mathrm{~m}$ height (excluding dwarf shrubs) cover more than two thirds of the area. Eighty percent of the shrublands in Switzerland are located in the subalpine zone. They are commonly neighboured by late-successional coniferous forests at their lower and by dwarf-shrub communities at their upper boundaries. Shrublands grow on sites which are at an early stage of reforestation after a recent land use change or where natural conditions, such as avalanches and soil lability, limit tree height and the establishment of tall trees. Typically, shrublands are dominated by a few woody species, which are optimally adapted to the prevailing environmental conditions. In the Swiss Alps, $70 \%$ of shrublands are formed by Alnus viridis DC., $20 \%$ by Pinus mugo TurRa subsp. mugo and $10 \%$ by Salix species, Corylus avellana L. and other woody species (Brändli 2010). Sediment records suggest that especially A. viridis was rare in pre-neolithic vegetation but became more abundant alongside the establishment of pastoralism (Schwörer et al. 2014). Because of the substantial expansion of shrubland in the Alps it is important to understand its effects on plant species diversity and how they depend on the environmental site conditions and shrub species.

Pasture-shrub transects are characterised by a gradual shift from one habitat (open pasture) to another (closed shrub). As suggested by Duelli (1992) our first hypothesis $\mathrm{H} 1$ was that maximum species richness appears in the intermediate transition zone. However, studies testing H1 are contradictory and show evidence for a decline (Pajunen et al. 2012; Ratajczak et al. 2012; Teleki et al. 2020), a linear increase (Howard et al. 2012; Knapp et al. 2008) as well as hump-shaped response of plant species richness to shrub cover (Anthelme et al. 2001, 2003, 2007; Kesting et al. 2015; Pornaro et al. 2013; Soliveres et al. 2014). Reported responses of faunal diversity to shrub encroachment are equally varying (Blaum et al. 2007; García-Tejero et al. 2013; Hilpold et al. 2018; Kaphengst and Ward 2008; Laiolo et al. 2004). No consistent theory has been developed regarding which response model applies under which conditions. For example, Soliveres et al. (2014) found a hump-shaped response of floral diversity in drylands and a linear negative response on wetter sites. In contrast, Pornaro et al. (2013) concluded that the response on subalpine sites was governed by mean temperature. Howard et al. (2012) demonstrated that shrubs generally had positive effects on plant diversity in semi-arid ecosystems. Based on this evidence, our second hypothesis $\mathrm{H} 2$ was that yetto-be-identified environmental conditions determine the response of plant diversity to shrub encroachment in the Swiss Alps.

In addition to environmental conditions, plant species identity may play an important role in recruitment speed and vegetation change. For example, Cairns and Moen (2004) have postulated that the speed of wood establishment under grazing may peak at low, intermediate or high grazing pressure depending on the relative palatability of herbaceous and arboreal vegetation. Loranger et al. (2017) found that tree species establishment interacted with grassland vegetation and that senescent herbs facilitate carbohydrate reserves in seedlings of evergreen trees. Modelling studies indicate that also the initial conditions may affect shrub encroachment (Komac et al. 2013). Hence, an analysis of vegetation dynamics at the pasture-shrub interface needs to take into account multiple contrasting sites.

Sampling vegetation across successional stages poses a number of challenges. Besides the difficulty of physical access and movement of the observer, sampling needs to account for heterogeneity and the different species-area relationship of open grassland and shrub forest (Rejmének and Rosén 1992). This is because the average size of individual plants changes by orders of magnitude from herbs to shrubs and because shrubs establish in patches (Wild and Winkler 2008). Moreover, processes such as plant competition, nutrient turnover or dispersal operate at different scales and hence, shrub cover may affect vegetation dynamics at local as well as larger scale. Since the $\mathrm{N}_{2}$-fixing shrub A. viridis is known to affect the environment beyond its own canopy zone (Bühlmann et al. 2016), our third hypothesis H3 was that various shrub species may differ in the spatial scale of their effects. An appropriate sampling method along transects of shrub cover, therefore, needed to take into account different spatial scales. 
The objectives of our study in the subalpine zone of the Swiss Alps were to test the three hypotheses developed above by (1) quantifying the impact of shrub encroachment on the plant species diversity across different environmental conditions (climate, topography and soil), (2) disentangling the effects of environmental conditions from those of dominant shrub species and (3) developing and testing an efficient and objective sampling method that accounts for different spatial scales of shrub effects.

\section{Materials and methods}

\section{Selection of pasture-shrub transects}

Potential transects from open pasture to closed shrubland within the subalpine zone (1300 m a.s.l. to $2400 \mathrm{~m}$ a.s.1.) of the Swiss Alps were identified by first selecting all cells of the Swiss land cover map (BFS 2013) that were classified as pastures (NOAS04 classes 42-49) and were directly adjacent to shrubland (NOAS04 class 57, excluding dwarf shrubs). Each selected cell was visually inspected using aerial imagery (Swissimage $25 \mathrm{~cm}$, Federal Office of Topography Swisstopo). We excluded cells with abrupt changes from pasture to shrubland due to fences, water courses, roads, topography or other features, leaving a total of 117 possible locations with a gradual change in shrub cover. The candidate locations were stratified according to geology (Calcareous and Flysch, Siliceous and Dolomite) and aspect (South, North, East/West). Many of the locations were spatially clumped, for example, in remote valleys with high abandonment. We therefore calculated the centred, standardized mean of the distances from each location to every other location and multiplied it by one of four quality grades $(0,1.5$, 3,6 ) based on transect length and the smoothness of shrub cover change. The resulting values were used as weights in the random sampling of eight transects in each of the six groups, which were verified on-site. Finally, 24 transects were selected that were reasonably accessible and had not been cleared in the time since the Swissimage had been captured (Fig. 1).

\section{Survey layout}

In the field, the pasture-shrub transect was marked by a central line. Along this line, five cover zones (hereafter labelled zonal cover, $c_{z}$ ) with an estimated shrub cover of $0,25,50$, 75 and $100 \%$ were marked by a pole (Fig. 2). The distances between poles varied depending on how quickly the shrub cover changed along the transect. Perpendicular to the

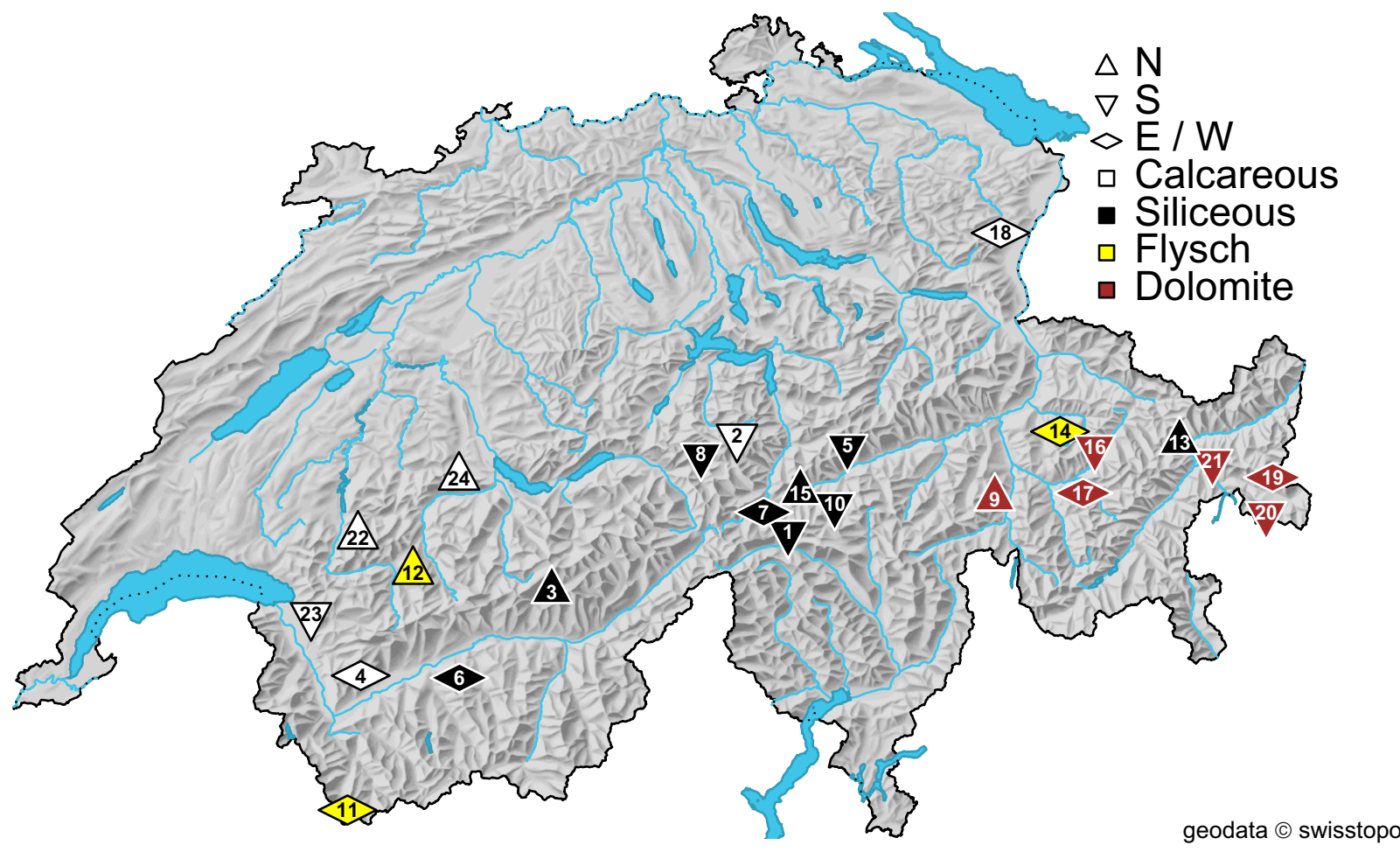

Fig. 1 Geographic location of sampled pasture-shrub transects in the Swiss Alps. Symbols indicate terrain aspect (upper triangles: North-West to North-East; lower triangles: South-East to South-West; rhombi: South-West to North-West and North-East to South-East). Colours indicate different substrates 


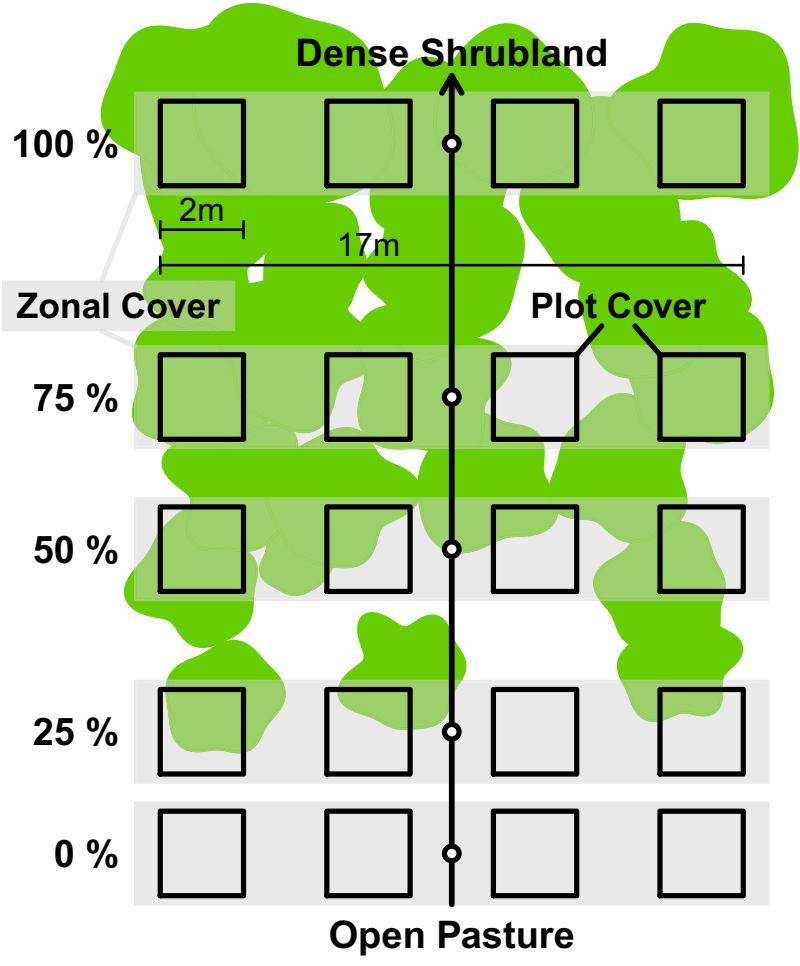

Fig. 2 Schematic representation of the sampling approach along a transect from open pasture to dense shrubland. The arrow represents the centre line along the transect. Small circles along the arrow indicate poles in five zones with estimated zonal cover of $0,25,50,75$ and 100\%. Quadrates show four sampling plots of $2 \times 2 \mathrm{~m}$ at fixed distances along lines perpendicular to the pasture-shrub transect. A value of plot cover was assessed for each sampling plot

central line, square plots of $2 \times 2 \mathrm{~m}$ were established at fixed distances of 2.5 and $7.5 \mathrm{~m}$ from each pole in both directions, minimizing subjectivity of plot placement. This resulted in four plots (at fixed distance of $3 \mathrm{~m}$ apart) in each of the five cover zones and a total of 20 plots at each location. Within each plot, shrub cover was visually estimated on a continuous scale (hereafter labelled plot cover, $c_{\mathrm{p}}$ ), in contrast to the discrete values of $c_{\mathrm{z}}$. At low to medium cover values, $c_{\mathrm{p}}$ was not necessarily similar to $c_{\mathrm{z}}$, because of the size of shrub patches. For example, a $2 \times 2 \mathrm{~m}$ plot randomly placed in the $50 \%$ cover zone may have a $c_{\mathrm{p}}$ anywhere between 0 and $100 \%$ depending on the presence of shrub patches. Both values, $c_{\mathrm{p}}$ and $c_{\mathrm{z}}$, are important and have different implications with respect to light and nutrient availability, as well as accessibility by grazing animals.

In each plot, all higher vascular plants were recorded and classified to the species level based on Lauber and Wagner (2007). Percentage cover $p_{\mathrm{k}}$ of each species $k$ was visually estimated, separately for the herb layer $(0-50 \mathrm{~cm}$ vegetation height, including woody species) and the shrub layer (woody species above $50 \mathrm{~cm}$ ). Herbaceous structures (stems, leaves and flowers) above $50 \mathrm{~cm}$ were not accounted for in the shrub layer. In addition, topsoil $(0-10 \mathrm{~cm})$ was sampled from each plot and analysed for plant-available phosphorus $(\mathrm{P})$ content, as an indicator of soil nutrient status, using ammonium acetate EDTA (Demaria et al. 2005) and pH in a soil-water suspension.

For each transect, additional environmental variables were quantified. Elevation and steepness were based on the digital terrain model of the Federal Office of Topography at $25 \mathrm{~m}$ resolution. Mean annual temperature and precipitation were extracted from climate data of the Federal Office of Meteorology and Climatology.

\section{Data analysis}

During data analysis, it became evident that pasture-shrub transects were dominated by a very limited number of woody species, mainly $A$. virdis and $P$. mugo. Therefore, Picea abies (L.) H. KARst., Rhamnus alpina L. and Salix appendiculata VILL. were aggregated into a third group labelled 'Others'. In order to assess species association to shrub cover, IndVal values were calculated for each of the 15 combinations $q$ of the five cover zones within the three dominant shrub species according to Dufrêne and Legendre (1997). The IndVal $\mathrm{kq}_{\mathrm{kq}}$ of a plant species $k$ in combination $q$ is defined as the ratio of the mean $p_{k}$ across plots in $q$ and the mean $p_{k}$ over all combinations multiplied by the ratio of the number of plots in $q$ where species $k$ is present and the total number of plots in $q$. With this approach, rare species present in a few plots of a combination only, are not mistaken as a species closely associated to that combination.

Plant species composition was represented by six vegetation-related indices: (1) Species richness $R_{\mathrm{i}}$ was calculated as the number of all species of each plot $i$. (2) Evenness was calculated based on the Shannon diversity index as $E_{i}=-\left(\sum_{k=1}^{R} p_{k} \ln p_{k}\right) / \ln R_{\mathrm{i}}$. (3) Beta-diversity was calculated as the average Jaccard distance (Jaccard 1901) of species composition in a plot to the three other plots in the same cover zone. (4) Nutrient, (5) light and (6) water requirement indices were calculated by averaging indicator values of all species $k$ according to Landolt and Bäumler (2010) weighted by their cover percentage $p_{k}$. Species richness, evenness and beta-diversity were calculated for the combined shrub and herb layers. Nutrient, light and water requirement indices were restricted to the herb layer only, in order to avoid confounding with shrub cover against which they were analysed.

Vegetation indices were analysed considering dominant shrub species, environmental variables, plot and zonal cover as well as their interactions. The complexity of the sampling structure of the data was accounted for by including transects and cover zones as random effects into a linear mixed-effects model. Diagnostic checks indicated that species richness and indicator values followed a normal likelihood, whereas evenness and beta-diversity were 
bounded between 0 and 1 and best modelled using a beta likelihood. Specifically, vegetation index $y_{i j g}$ in plot $i=1$, $\ldots, 480$ in cover zone $j=1, \ldots, 120$ of transect $g=1, \ldots$, 24 was $\mathrm{y}_{\mathrm{ijg}} \sim \mathrm{N}\left(\mu_{\mathrm{ijg}}, \sigma\right)$ for species richness and requirement indices and $\mathrm{y}_{\mathrm{ijg}} \sim \mathrm{B}\left(\mu_{\mathrm{ijg}}, \varphi\right)$ for evenness and beta-diversity, where

$$
\begin{aligned}
f\left(\mu_{i j g}\right)= & \beta_{0}+\beta_{1} s_{g}+\beta_{2} c_{j}+\beta_{3} c_{j}^{2}+\beta_{4} d_{c}+\beta_{5} c_{j} s_{g}+\beta_{6} c_{j}^{2} s_{g}+\beta_{7} d_{c} s_{g} \\
& +\beta_{8} v_{g}+\beta_{9} c_{j} v_{g}+\beta_{10} c_{j}^{2} v_{g}+b_{1 j}+b_{2 g}+b_{3 g} c_{j}+b_{4 g} c_{j}^{2}
\end{aligned}
$$

and

$b_{1 j} \sim \mathrm{N}\left(0, \sigma_{1}\right),\left(b_{2 g}, b_{3 g}, b_{4 g}\right)^{\mathrm{T}} \sim \mathrm{N}(0, \Sigma)$

Link function $f()$ was specified as identity for the normal likelihood and logit for the beta regression models. The independent variable $s_{\mathrm{g}}$ was the dominant shrub species in transect $g$. Variables $c_{\mathrm{j}}$ and $c_{\mathrm{j}}^{2}$ were shrub cover and its square, standardized and centred in zone $j$. Including $c_{\mathrm{j}}^{2}$ allowed for the inclusion of a potential hump-shaped relationship. Models were run with either plot cover $c_{\mathrm{p}}$ and its square $c_{\mathrm{p}}^{2}$, or zonal cover $c_{\mathrm{z}}$ and its square $c_{\mathrm{z}}^{2}$. Variable $d_{\mathrm{c}}$ was the standardized difference between the two shrub cover variables $c_{\mathrm{p}}$ and $c_{\mathrm{z}}$. The reason for using cover difference $d_{\mathrm{c}}$ was that $c_{\mathrm{p}}$ and $c_{\mathrm{z}}$ were strongly collinear and including them individually would hinder stable model fitting. Variable $v_{\mathrm{g}}$ was an environmental covariate at the transect level, e.g. steepness. Initially, several covariates were included analogously, but only one is shown in Eq. 1. Environmental covariates $\left(v_{\mathrm{g}}\right)$ were reduced with stepwise likelihood-ratio tests based on significance $P>0.05$ (Table $3 \mathrm{~b}$ ) and compared to the models with dominant shrub species as predictors based on the Akaike information criterion (AIC), log-likelihood and $R^{2}$. The terms $\beta_{0}-\beta_{10}$ were coefficients for the fixed effects and their interactions. Coefficients $b_{1 \mathrm{j}}$ were random intercepts for cover zones within transects accounting for the pseudo replication arising from the four dependent plots within each cover zone. Term $b_{2 \mathrm{~g}}$ were random intercepts for transects, $b_{3 \mathrm{~g}}$ and $b_{4 \mathrm{~g}}$ were random slopes for zonal cover and its square allowing for individual response curves at each transect. The $\Sigma$ was a general $3 \times 3$ positive-definite variance-covariance matrix.

All models were fitted to the data with maximum likelihood using packages lme (Pinheiro and Bates 2000) and glmmADMB (Fournier et al. 2012) in R 3.6.3 (R Core Team 2020). Marginal and conditional $R^{2}$ were calculated according to Nakagawa and Schielzeth (2012). Estimates and predictions are presented for the model with the lowest AIC. Predictions for individual transects were obtained based on the estimated random coefficients $b_{2}, b_{3}$ and $b_{4}$ for each transect $g$. Overall trends were predicted based on fixed effects coefficients and the global mean of $d_{c}$.
The data used to fit the linear models are available at https://doi.org/10.5281/zenodo.3886472. More detailed vegetation data is available upon request to the authors.

\section{Results}

\section{Characteristics of pasture-shrub transects}

The selected transects were evenly distributed across the Swiss Alps and ranged from 1300 to $2200 \mathrm{~m}$ a.s.l. with a mean elevation of $1786 \pm 253 \mathrm{~m}$ (Table 1). All transects were on slopes ranging from moderate $(19 \%)$ to very steep $(>70 \%)$. Annual precipitation ranged from $830 \mathrm{~mm}$ in the inner-alpine Engadine valley (transect 19 in Fig. 1) to $2070 \mathrm{~mm}$ in the wet Northern Alps (transect 18). In all 480 plots, a total of 483 plant species were identified in the herb layer and 23 woody species in the shrub layer. Plant species richness per plot $(2 \mathrm{~m} \times 2 \mathrm{~m})$ averaged 25.4 and ranged from 4 to 52, while plant species richness per transect (20 plots) averaged 98.9 and ranged from 54 to 146 . On average, each plot contained 0.9 shrub species. A. viridis was the dominant shrub species in 15 of the 24 sampled transects, followed by $P$. mugo (6 transects). P. abies, R. alpina and $S$. appendiculata each dominated one transect. $P$. abies is not a shrub species in the strict sense, but this transect was still included in NOAS04 class 57 of the Swiss land cover map because of the small size of the trees. The three transects of other species were mainly located at the Western border of the Swiss Alps, whereas transects dominated by P. mugo were situated more towards the East. No such pattern was obvious for transects dominated by $A$. viridis.

Transects significantly differed in elevation, with $P$. mugo dominating high $(2020 \pm 280 \mathrm{~m})$, A. viridis intermediate (1761 $\pm 160 \mathrm{~m}$ asl.) and other shrub species low elevations (1440 $\pm 108 \mathrm{~m}$; Fig. 3). Correspondingly, mean annual temperature for transects dominated by $P$. mugo $\left(0.8 \pm 2{ }^{\circ} \mathrm{C}\right)$ was significantly lower $(P<0.05)$ than that of transects dominated by other shrub species $\left(4.3 \pm 0.6{ }^{\circ} \mathrm{C}\right)$. Transects dominated by the three dominant shrub species $A$. viridis, $P$. mugo and others did not differ significantly in steepness, annual precipitation, soil phosphorus or soil $\mathrm{pH}$. For steepness and precipitation, the lack of significance may also be due to the large variability between transects and relatively small sample sizes. Because all transects were located in the transition zone between pasture and dense shrubland, they did not differ in their distance to old stands, on the one hand, or grazed areas, on the other. 
Table 1 Environmental descriptors for the 24 transects surveyed across the Swiss Alps

\begin{tabular}{|c|c|c|c|c|c|c|c|}
\hline $\mathrm{Nr}$ & Aspect & Geology & Dominant shrub species & $\begin{array}{l}\text { Elevation } \\
\text { (m a.s.l.) }\end{array}$ & Steepness (\%) & $\begin{array}{l}\text { Precipitation } \\
\left(\mathrm{mm} \mathrm{y}^{-1}\right)\end{array}$ & $\begin{array}{l}\text { Mean annual } \\
\text { temperature } \\
\left({ }^{\circ} \mathrm{C}\right)\end{array}$ \\
\hline 1 & $S$ & Siliceous & Alnus viridis & 1798 & 59 & 1722 & -2 \\
\hline 2 & $\mathrm{~N}$ & Calcareous & Alnus viridis & 1297 & 51 & 1703 & 3 \\
\hline 3 & $\mathrm{~N}$ & Siliceous & Alnus viridis & 1657 & 60 & 1099 & 4 \\
\hline 4 & $\mathrm{E} / \mathrm{W}$ & Calcareous & Alnus viridis & 1875 & 48 & 1509 & 2 \\
\hline 5 & $\mathrm{~S}$ & Siliceous & Alnus viridis & 1820 & 67 & 1597 & 2 \\
\hline 6 & $\mathrm{E} / \mathrm{W}$ & Siliceous & Alnus viridis & 1812 & 56 & 967 & 2 \\
\hline 7 & $\mathrm{E} / \mathrm{W}$ & Siliceous & Alnus viridis & 1677 & 56 & 1495 & 2 \\
\hline 8 & $S$ & Siliceous & Alnus viridis & 1783 & 73 & 1934 & 2 \\
\hline 9 & $\mathrm{~N}$ & Dolomite & Alnus viridis & 1953 & 65 & 1283 & 2 \\
\hline 10 & $\mathrm{~S}$ & Siliceous & Alnus viridis & 1707 & 61 & 1677 & 2 \\
\hline 11 & $\mathrm{E} / \mathrm{W}$ & Flysch & Alnus viridis & 1961 & 43 & 1353 & 2 \\
\hline 12 & $\mathrm{~N}$ & Flysch & Alnus viridis & 1758 & 36 & 1562 & 3 \\
\hline 13 & $\mathrm{~N}$ & Siliceous & Alnus viridis & 1840 & 57 & 953 & 0 \\
\hline 14 & $\mathrm{E} / \mathrm{W}$ & Flysch & Alnus viridis & 1829 & 56 & 1276 & 3 \\
\hline 15 & $\mathrm{~N}$ & Siliceous & Alnus viridis & 1653 & 54 & 1312 & 3 \\
\hline 16 & $\mathrm{~S}$ & Dolomite & Pinus тияо & 1981 & 32 & 1081 & 0 \\
\hline 17 & $\mathrm{E} / \mathrm{W}$ & Dolomite & Pinus mиgo & 2180 & 74 & 982 & 1 \\
\hline 18 & $\mathrm{E} / \mathrm{W}$ & Calcareous & Pinus mиgo & 1472 & 51 & 2070 & 5 \\
\hline 19 & $\mathrm{E} / \mathrm{W}$ & Dolomite & Pinus тиgo & 2185 & 19 & 837 & -1 \\
\hline 20 & $\mathrm{~S}$ & Dolomite & Pinus тияо & 2192 & 32 & 889 & 0 \\
\hline 21 & $\mathrm{~S}$ & Dolomite & Pinus mugo & 2109 & 48 & 1137 & 0 \\
\hline 22 & $\mathrm{~N}$ & Calcareous & Picea abies ${ }^{l}$ & 1396 & 34 & 1552 & 5 \\
\hline 23 & S & Calcareous & Rhamnus alpina ${ }^{l}$ & 1562 & 30 & 1738 & 4 \\
\hline 24 & $\mathrm{~N}$ & Calcareous & Salix appendiculata ${ }^{l}$ & 1360 & 46 & 1694 & 4 \\
\hline
\end{tabular}

Transects were selected in strata of aspect and geology with distance-specific weights to avoid clustering

${ }^{1}$ Pooled to shrub species ,Other ${ }^{6}$

\section{Explanatory power of environmental conditions and dominant shrub species}

In order to test hypothesis $\mathrm{H} 2$, we compared models describing the response of species richness in dependence of environmental conditions or dominant shrub species. The three most important models are shown in Table 2. Model 1, containing the full set of eight environmental variables (Table 2), had the highest $R^{2}$ of all evaluated models but was penalized for the high number of parameters and resulted in a high AIC (lower is better, i.e. more parsimonious). Reducing model 1 by successive likelihood-ratio tests led to model 2, with only steepness and geology. However, the models based on environmental variables were less parsimonious than model 3 , which considered effects of the three dominant shrub species. The conditional $R^{2}{ }_{\mathrm{c}}$ of models 3 and 1 were similar, although model 3 contained only the shrub species instead of the eight environmental variables and therefore resulted in a much lower AIC. Therefore, dominant shrub species is a strong predictor of the response of species richness to shrub cover.

\section{Explanatory power of zonal and plot cover and their difference}

The sampling protocol was able to catch the small-scale patchiness within intermediate cover zones (Fig. 4). In the $0 \%$ cover zone, plot cover $\left(c_{\mathrm{p}}\right)$ was always $0 \%$ because there were no scattered shrubs in this zone. In the 25,50 and $75 \%$ cover zones, half of the values of observed $c_{\mathrm{p}}$ (the gray boxes in Fig. 4) spanned $48 \%$, on average. In the $100 \%$ cover zone, observed $c_{\mathrm{p}}$ was less variable but a few very low values were observed (shrub gaps). In addition, $c_{z}$ was generally slightly overestimated in comparison to $c_{\mathrm{p}}$.

In order to test hypothesis $\mathrm{H} 3$, we evaluated models for plant species richness run with either $c_{z}$ or $c_{\mathrm{p}}$ and the cover difference $d_{\mathrm{c}}$ as predictors (Table 3). Using $c_{\mathrm{Z}}$ (model 3 ) resulted in a higher conditional $R_{\mathrm{c}}^{2}$ and lower AIC compared 
(a)

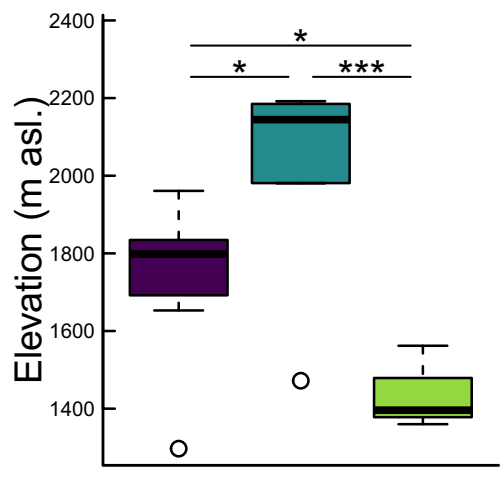

(d)

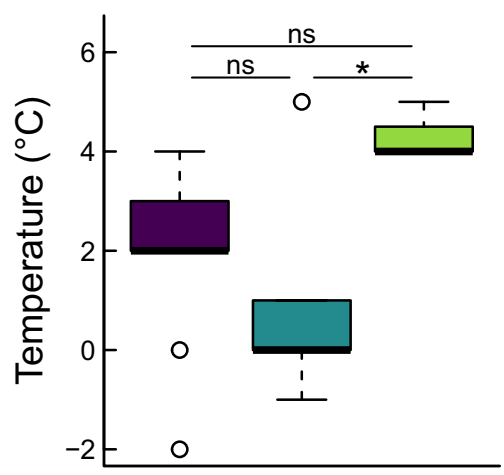

(b)

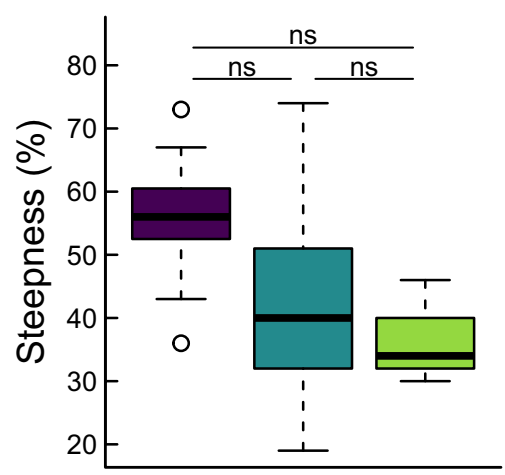

(e)

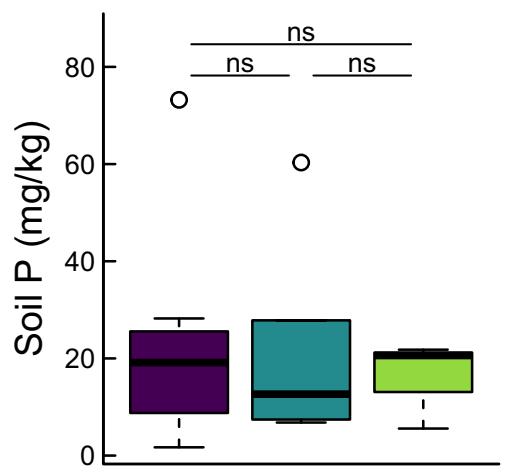

(c)

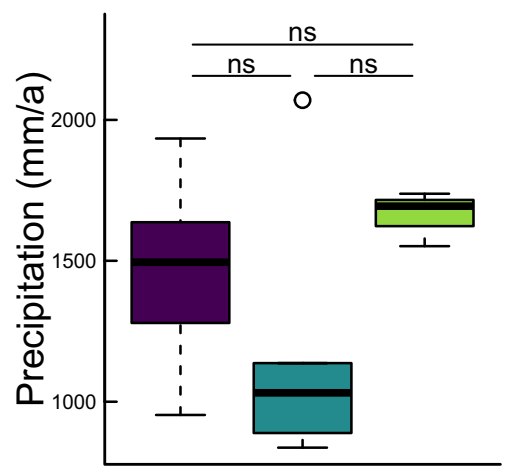

(f)

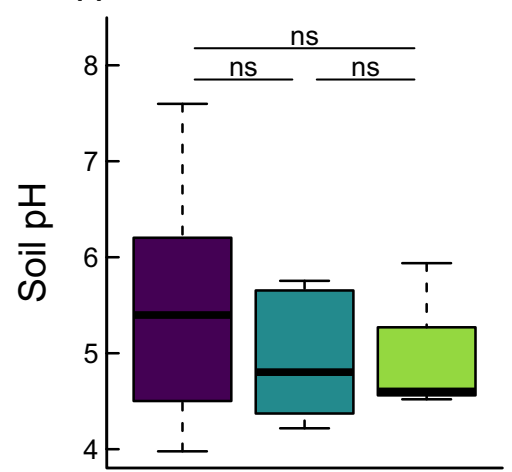

Alnus viridis $\square$ Pinus mugo $\square$ Others

Fig. 3 Differences in environmental variables among transect dominated by Alnus viridis, Pinus mugo and other shrub species. Elevation and steepness are based on the digital terrain model of the Federal Office of Topography Swisstopo. Mean annual temperature and precipitation based on climate data of the Federal Office of Meteorology and Climatology MeteoSwiss. Soil P values were determined by

to using $c_{\mathrm{p}}$ (model 4). Removing the cover difference (model $5)$ reduced $R^{2}$ and increased the AIC.

\section{Effects of shrub cover and shrub species on plant species richness}

Predictions based on the most parsimonious model 3 indicate that a high $c_{\mathrm{z}}$ was usually associated with low plant species richness (Fig. 5). On average, species richness at $100 \%$ shrub cover was $48.9 \%$ of that in open pasture $(0 \%$ shrub cover). This reduction was observed in every transect except transect 23 , in which an average of 20.8 species were recorded at $0 \%$ cover and 21.6 species at $100 \%$ cover. This transect was dominated by $R$. alpina and characterized by a comparatively low elevation, high precipitation and high mean annual temperature. In 20 of the 24 transects, highest species richness, averaged over the four plots of a ammonium acetate EDTA and $\mathrm{pH}$ in a soil-water suspension. Boxes show 25th-75th quartile ranges (IQR); line: median; whiskers: max. 1.5 IQR; points: outliers. Lines and asterisks above the boxplot indicate results of pairwise Tukey test at $* * * P<0.001, * P<0.05$, $n s$ not significant

cover zone, was observed at 0 or $25 \%$ shrub cover. In the remaining four transects the maximum species richness was observed at $50 \%$ (transects 2, 16 and 22) and 75\% shrub cover (transect 23). Moreover, mean species richness was among the highest in these transects.

Plant species richness was not directly associated with dominant shrub species. The mean number of species per plot in transects dominated by $P$. mugo was only 2.8 species higher than in transects dominated by $A$. viridis (estimated coefficient of the difference $=2.8$; not significant; Table 4). Transects dominated by other shrub species contained 3.6 species more (not significant) than those dominated by $A$. viridis.

In contrast, the effects of shrub cover on species richness were strongly associated with dominant shrub species. In transects dominated by $A$. viridis, species richness strongly declined with increasing shrub cover. The decline 
Table 2 Goodness of fit measures for models of plant species richness regressed on different environmental variables and dominant shrub species

\begin{tabular}{llllll}
\hline ID & Model & $R_{\mathrm{m}}^{2}$ & $R_{\mathrm{c}}^{2}$ & AIC & $\operatorname{LogLik}$ \\
\hline 1 & $c_{\mathrm{z}}+c_{\mathrm{z}}^{2}+d_{\mathrm{c}}+G+S t$ & 0.664 & 0.793 & 3093.4 & -1490.7 \\
& $+A+E+P r+P+T$ & & & & \\
& $+p H$ & & & & \\
2 & $\mathrm{c}_{\mathrm{z}}+c_{\mathrm{z}}^{2}+d_{\mathrm{c}}+G+S t$ & 0.595 & 0.792 & 3067.7 & -1505.8 \\
$\mathbf{3}$ & $\boldsymbol{c}_{\mathbf{z}}+\boldsymbol{c}_{\mathbf{z}}^{2}+\mathbf{d}_{\mathbf{c}}+\mathbf{S}$ & $\mathbf{0 . 5 0 3}$ & $\mathbf{0 . 7 9 2}$ & $\mathbf{3 0 6 1 . 6}$ & $\mathbf{- 1 5 1 0 . 8}$
\end{tabular}

The final model 3 is shown in bold. Not all intermediate models are shown. $R^{2}{ }_{m}$ variance explained by the fixed effects, $R^{2}{ }_{c}$ variance explained by both the fixed and the random effects, AIC Akaike information criterion, LogLik log likelihood, $c_{z}$ zonal cover, $c_{z}^{2}$ squared zonal cover, $d_{c}$ cover difference $c_{\mathrm{z}}-c_{\mathrm{p}}, G$ geology (four classes: Calcareous, Dolomite, Flysch, Siliceous), St steepness, $A$ aspect (three levels: North, South, East/West), $E$ elevation, $\operatorname{Pr}$ annual precipitation, $P$ soil phosphorous, $T$ mean annual temperature, $p H$ soil $\mathrm{pH}, S$ dominant shrub species (three classes: A. viridis, $P$. mugo and Others)

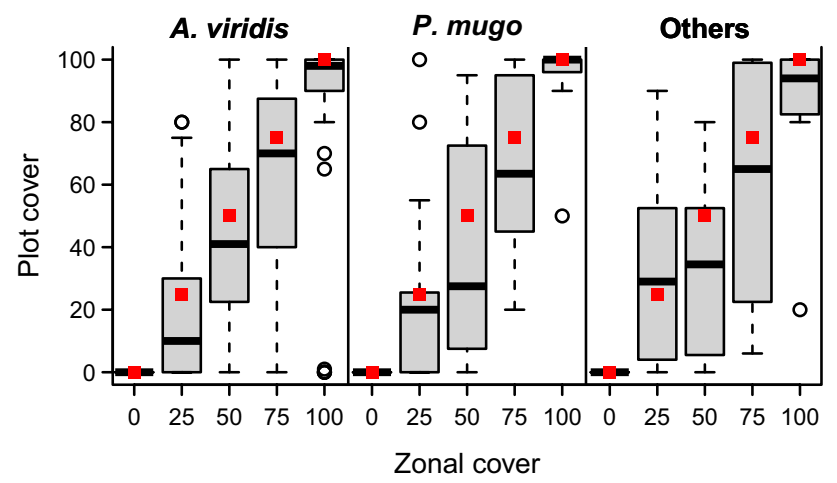

Fig. 4 Distribution of observed plot cover (boxplots) in cover zones (red squares) of the three dominant shrub species Alnus viridis, Pinus mugo and others. Boxes show 25th-75th quartile ranges (IQR); line: median; whiskers: max. $1.5 \cdot \mathrm{IQR}$; points: outliers

Table 3 Goodness of fit measures for models of plant species richness regressed on zonal cover $\left(c_{\mathrm{z}}\right)$ or plot cover $\left(c_{\mathrm{p}}\right)$ an their difference $\left(d_{c}\right)$

\begin{tabular}{llllll}
\hline ID & Model & $R_{\mathrm{m}}^{2}$ & $R^{2}{ }_{\mathrm{c}}$ & AIC & LogLik \\
\hline $\mathbf{3}$ & $\boldsymbol{c}_{\mathbf{z}}+\boldsymbol{c}_{\mathrm{z}}^{2}+\mathbf{d}_{\mathbf{c}}+\mathbf{S}$ & $\mathbf{0 . 5 0 3}$ & $\mathbf{0 . 7 9 2}$ & $\mathbf{3 0 6 1 . 6}$ & $\mathbf{- 1 5 1 0 . 8}$ \\
4 & $c_{\mathrm{p}}+c_{\mathrm{p}}^{2}+d_{\mathrm{c}}+S$ & 0.483 & 0.788 & 3101.7 & -1530.9 \\
5 & $c_{\mathrm{z}}+c_{\mathrm{z}}^{2}+S$ & 0.486 & 0.777 & 3089.8 & -1527.9 \\
\hline
\end{tabular}

The final model 3 is shown in bold. $R_{m}^{2}$ variance explained by the fixed effects, $R^{2}$ c variance explained by both the fixed and the random effects, AIC Akaike information criterion, LogLik log likelihood, $c_{z}$ zonal cover, $c_{z}^{2}$ squared zonal cover, $c_{p}$ plot cover, $c_{p}^{2}$ squared plot cover, $d_{\mathrm{c}}=c_{\mathrm{p}}-c_{\mathrm{z}}, S$ dominant shrub species (three classes: A. viridis, P. mugo and others) was linear with a decrease of -21.6 species $(P=0.001)$ across the entire range of the transect and with no effect of squared cover (coefficient of $-0.54 ; P=0.93$ ). For $A$. viridis-dominated transects, a maximum of 33.9 species per plot was estimated to occur in open pasture, which dropped to only 12.8 species ( $38 \%$ of maximum) in dense shrub. The response of plant species richness to the cover of $P$. mugo was concave. A linear slope of $9.3(P=0.36)$ and an effect of squared cover of $-24.6(P=0.008)$ resulted in a humpshaped response with a maximum of 34.6 species per plot at $19 \%$ shrub cover. In open pasture, 33.9 species (97\% of maximum) were estimated and 18.6 species (54\% of maximum) were estimated for closed shrubs. Transects dominated by other shrub species also showed a concave response pattern with a peak at $42 \%$ shrub cover with an estimate of 36.9 species. With estimated coefficients of $32.5(P=0.03)$ for the linear term and $-38.6(P=0.004)$ for the squared term, the concave shape was more pronounced than for $P$. mugo. Estimates at 0 and $100 \%$ shrub cover were 30.1 and 23.9 species ( 81 and $65 \%$ of maximum), respectively. Even though only three transects were dominated by other shrub species, estimates were significantly different from the $A$. viridis-dominated transects.

The estimates of the cover difference $d_{\mathrm{c}}$ indicated that the two cover measures $c_{\mathrm{z}}$ and $c_{\mathrm{p}}$ acted additively on plant species richness. In transects dominated by $A$. viridis and $P$. mugo, cover difference $\left(d_{\mathrm{c}}=c_{\mathrm{p}}-c_{\mathrm{z}}\right)$ had a significant negative effect $(P<0.001)$ on plant species richness. Hence, in cases where $c_{\mathrm{p}}>c_{\mathrm{z}}$, species richness was lower. For example, if a plot located in the 50\% cover zone $\left(c_{z}\right)$ of $A$. viridis had a local shrub cover $\left(c_{\mathrm{p}}\right)$ of $70 \%$, species richness was reduced by $-4.2 \cdot 0.2=-0.84$ species. The estimated effect of cover difference was lower $(P=0.03)$ for $P$. mugo than for $A$. vir$i d i s$, indicating that species richness in $P$. mugo transects was more locally influenced by $c_{\mathrm{p}}$ than in transects dominated by $A$. viridis. In case of $70 \%$ plot cover of $P$. mugo in the $50 \%$ cover zone, the reduction was $-(4.6+5.7) \cdot 0.2=-2.0$ species. The marginal effect of $d_{\mathrm{c}}$ in transects dominated by other shrub species indicated that species richness was predominately determined by $c_{\mathrm{z}}$.

\section{Effects of shrub cover and shrub species on evenness and beta-diversity of plant species}

The model of species evenness was simpler than that of species richness because $c_{\mathrm{z}}^{2}$ was insignificant and omitted $(P>0.05)$. Compared to $A$. viridis-dominated gradients, evenness was similar in $P$. mugo-dominated gradients and significantly higher for those dominated by other shrub species $(P=0.01)$. Evenness of species abundance linearly decreased with increasing shrub cover $(P>0.001)$, that is, vegetation in dense shrub was dominated by fewer plant species. The decrease of evenness with shrub cover was 
(a)
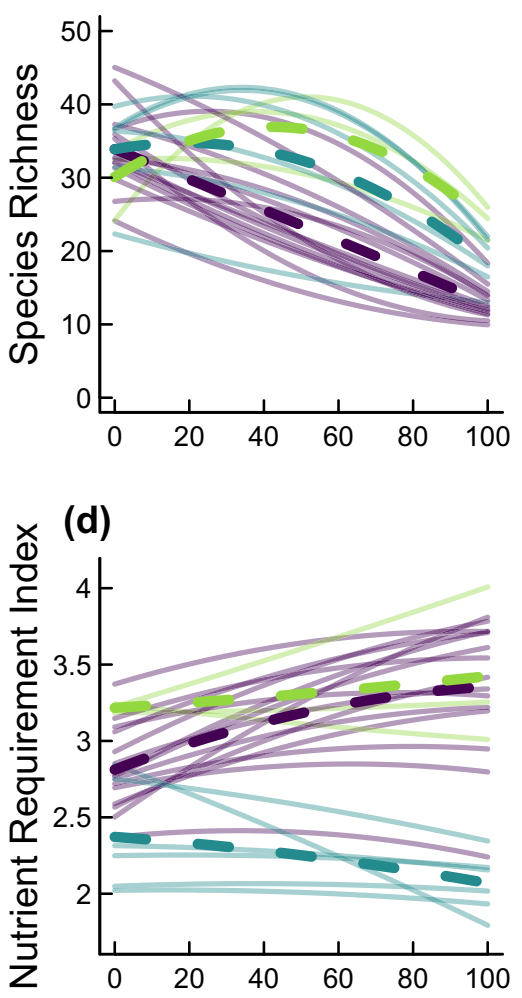

(b)

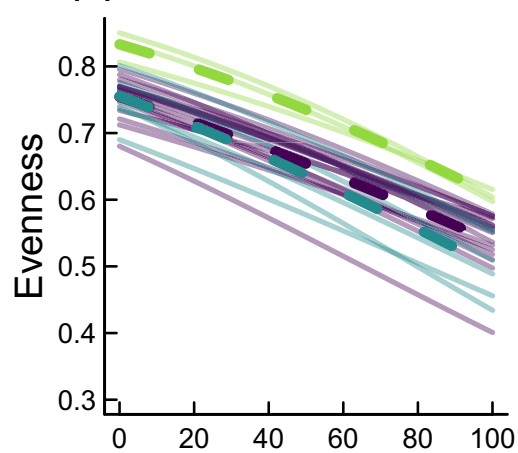

(e)

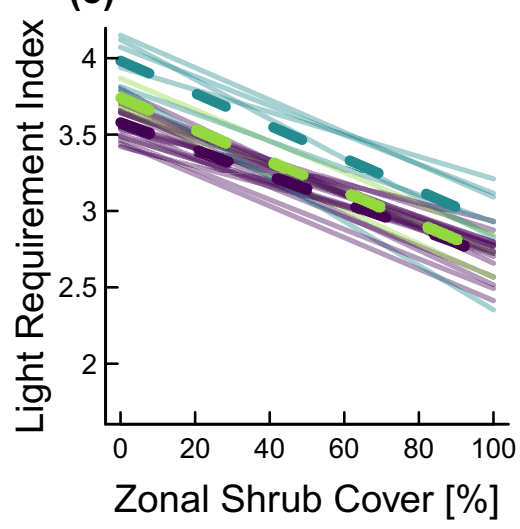

(c)

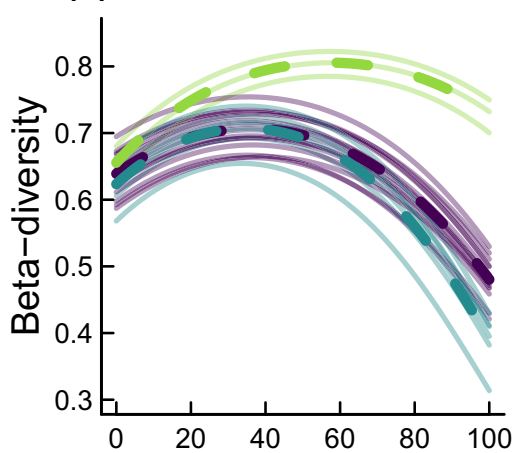

(f)

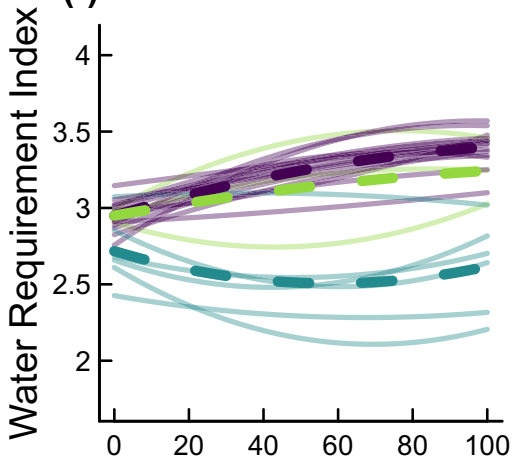

Alnus viridis

Pinus mugo

Other

Fig. 5 Predictions of a plant species richness, $\mathbf{b}$ evenness, $\mathbf{c}$ betadiversity, $\mathbf{d}$ nutrient requirement index, $\mathbf{e}$ light requirement index and f water requirement index regressed on zonal shrub cover. Bold dotted lines were predicted based on linear mixed-effects models with the fixed terms zonal cover and dominant shrub species. Thin, solid lines were predicted with zonal cover, dominant shrub species and random effect estimates of each transect

peaked at $57 \%$ shrub cover and were $81 \%$ and $90 \%$ of the maximum in open pasture and closed shrub, respectively.

\section{Effects of shrub cover and shrub species on nutrient, light and water requirement indices}

Plant species in the herb layer of transects dominated by $P$. mugo had a significantly lower nutrient requirement index than those dominated by $A$. viridis $(P>0.001)$. Transects dominated by other shrub species and $A$. viridis did not differ significantly. The nutrient requirement index significantly increased (est $=0.93 ; P<0.001)$ with the cover of $A$. viridis. An increasing cover of $P$. mugo and other shrub species did not change the nutrient requirement index of plants in the herb layer (est $=-0.18 ; P=0.62$ and est $=0.15 ; P=0.76$, respectively). 


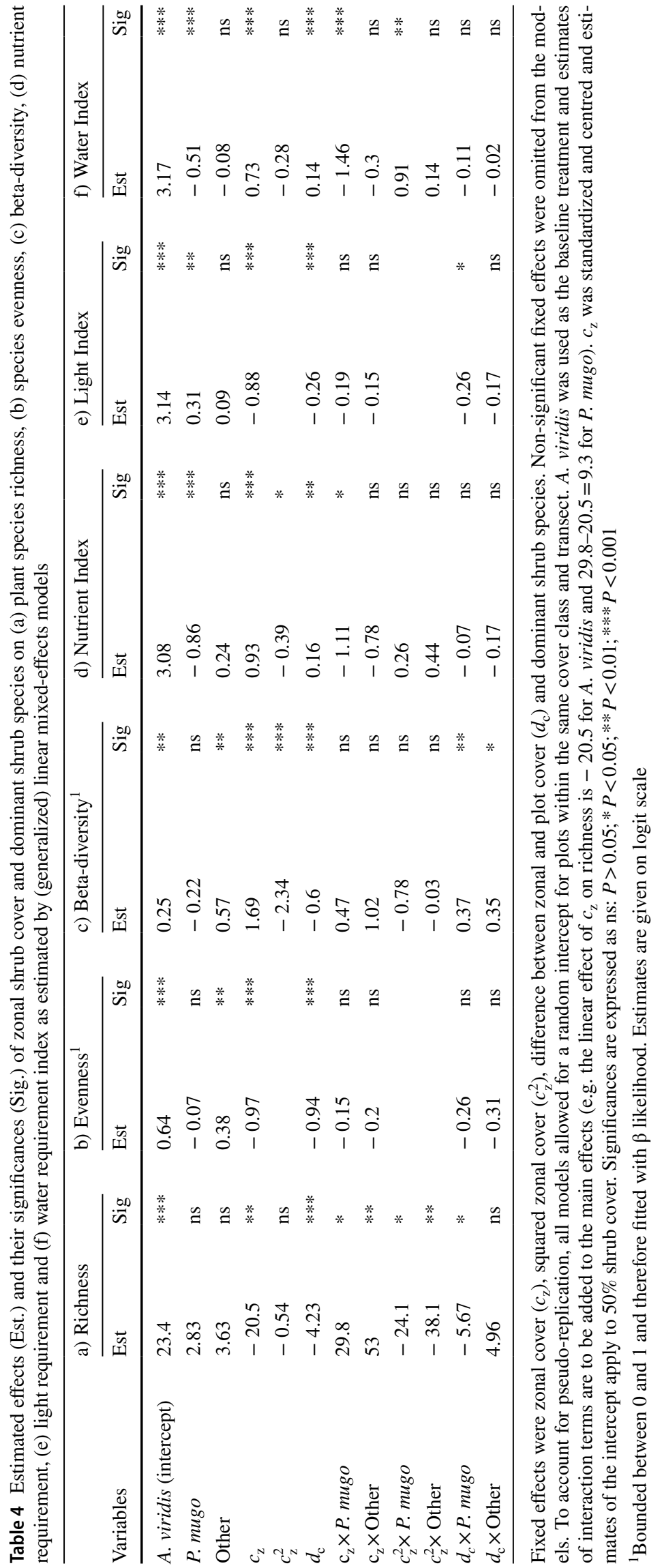


The light requirement index of the herb layer in transects dominated by $P$. mugo was significantly higher than that of $A$. viridis-dominated transects $(P<0.001)$, transects dominated by other shrub species and by $A$. viridis did not differ. The light requirement index significantly decreased with the cover of $A$. viridis $(P<0.001)$. The cover of $P$. mugo and other shrub species tended to have a weaker effect on the light requirement index.

The water requirement index of plants in the herb layer was significantly higher for transects dominated by $A$. viridis and other species than by $P$. mugo $(P<0.001)$. There was a significant increase in water requirement of the herb-layer vegetation at higher cover of $A$. viridis and other shrub species $(P<0.001)$. Water requirement indices of vegetation were lowest at intermediate levels of $P$. mugo.

\section{Species association to dominant shrub species and zonal shrub cover}

The IndVal analysis clearly associated several typical plant species to each of the dominant shrub species (Fig. 6). At $100 \%$ shrub cover in A. viridis-dominated transects, it

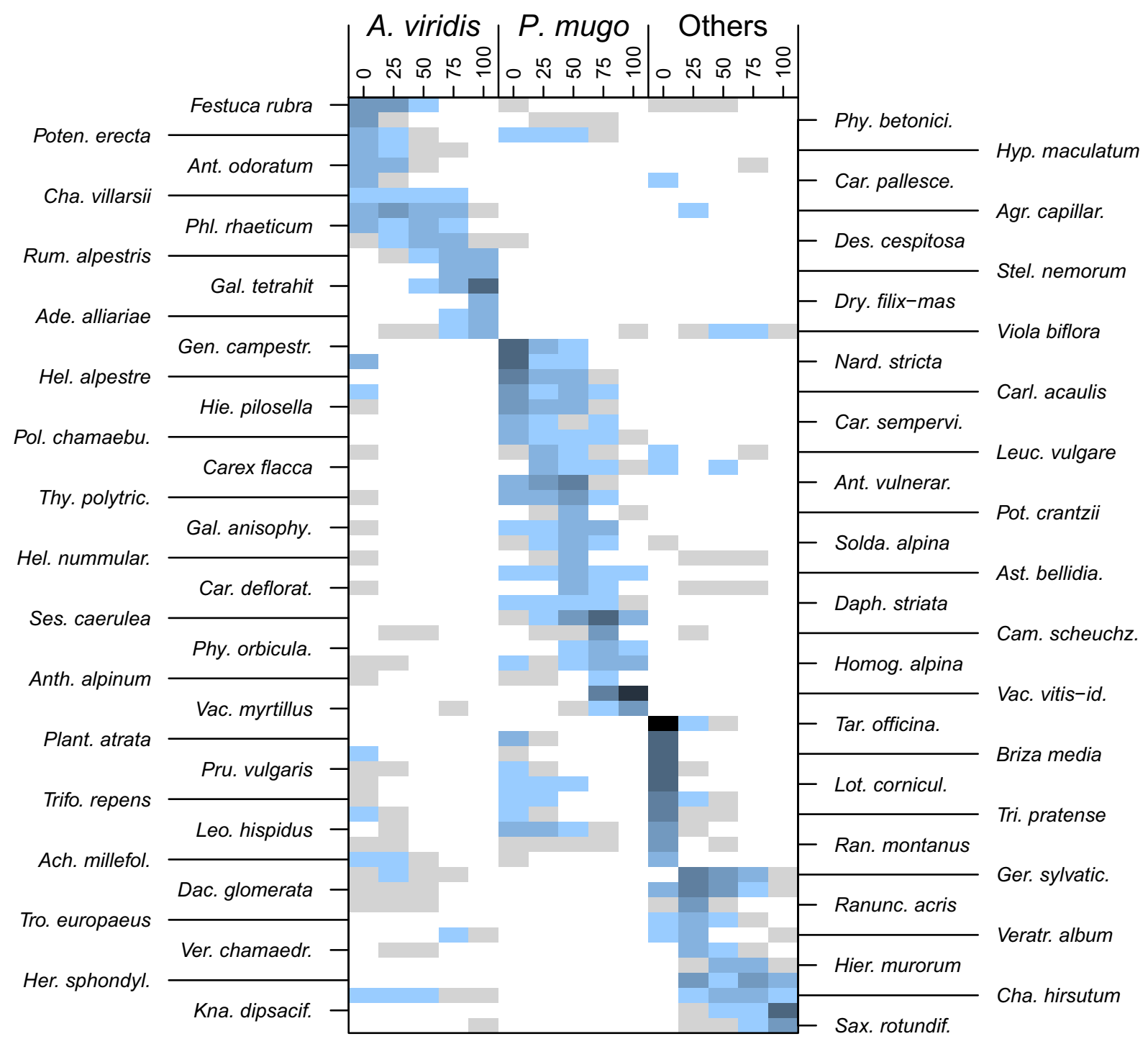

IndVal:

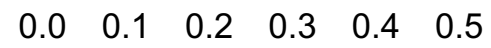

Fig. 6 Strength of association between plant species and combinations of dominant shrub species and zonal shrub cover, as quantified by IndVal values according to Dufrêne and Legendre (1997). IndVal values indicate how uniquely a species is associated to the cover zone of a given shrub species. Species ordered according to strongest association (several associations possible) 
identified a very distinct plant species community with a high number of strongly associated species, such as the tall forb Adenostyles alliariae (GouAN) A. KERN. or the fern Dryopteris filix-mas (L.) Sснотт. The dwarf shrubs Vaccinium vitis-idea L. and V. myrtillus L. were strongly associated with dense stands of $P$. mugo. High cover of other shrub species favoured Knautia dipsacifolia KREUTZER and Saxifraga rotundifolia $\mathrm{L}$.

At low shrub cover values (open pasture), species were non-specific and were present irrespective of the dominant shrub species, as demonstrated by the numerous additional ties to other cover zones outside the shrub species when vertically following the $0 \%$ cover zones in Fig. 5: For instance, species like Nardus stricta L., Carlina acaulis L., Hieracium pilosella $\mathrm{L}$. and others were most strongly associated with open pastures ( $0 \%$ shrub cover) in P. mugo-dominated transects, but also had a significant association with the open pastures of A. viridis dominated transects. These associations with multiple dominant shrub species diminished as shrub cover levels increased. Hence, species at $100 \%$ shrub cover were distinctly associated with only one shrub species. Likewise, reading Fig. 5 horizontally shows that species growing in plots within $100 \%$ cover zones were also abundant in plots of other cover zones of the same dominant shrub species, but were rarely found in the herb layer of other dominant shrub species. In turn, species associated with low cover values have ties to other dominant shrub species, but only at cover values below $75 \%$.

The change of species association along the pasture-shrub transect differed for the dominant shrub species. The lowest number of indicator species among the dominant shrub species was found for $A$. viridis. The change in species composition from open pastures to closed $A$. viridis was very sudden, with only a few indicator species found at intermediate levels. Transects of $P$. mugo showed a more gradual change of species composition with very few species associated with one specific proportion of shrub cover. The most distinct change in species composition from one cover zone to the next was observed in transects dominated by other shrub species. There was very little overlap between species at the $0 \%$ cover zone and species found between 25 and $100 \%$ shrub cover. In addition, these species had few similarities to A. viridis-dominated transects and none to those dominated by $P$. mugo.

\section{Discussion}

\section{Drivers of botanical composition along pasture-shrub transects}

Our investigation of 24 pasture-shrub transects in the subalpine zone of the Swiss Alps showed that the dominant shrub species is a parsimonious predictor of vegetation response along pasture-shrub transects. Environmental conditions such as elevation and geographic location also tended to affect the distribution of shrub species. For instance, A. viridis was typically dominating mid-elevation transects on siliceous substrate with northern aspect. However, A. viridisdominated transects 2 and 4 had calcareous substrate and transects 1, 5, 8 and 10 had south-facing slopes, in line with Caviezel et al. (2017). Since each shrub species generally prefers certain environmental conditions, these conditions are already implicitly included in the factor shrub species. Thus, adding environmental variables in the model did not improve the prediction of vegetation response beyond the explanatory power of the three major shrub species. Hence, the data did not confirm our hypothesis $\mathrm{H} 2$ that environmental conditions are the primary determinant of the response of vegetation to shrub cover as suggested by earlier investigations in various biomes (Howard et al. 2012; Pornaro et al. 2017; Soliveres et al. 2014).

A further reason for the strong explanatory power of dominant shrub species may be that shrub species modify growth conditions by their presence. While such interactions have been well described for P. mugo (Wild and Winkler 2008), they are special for $A$. viridis, which is able to fix atmospheric $\mathrm{N}_{2}$ by symbiotic bacteria of the species Frankia alni (1997). Leave and root litter of A. viridis are N-rich and their decomposition releases $\mathrm{N}$ into the environment and causes eutrophication (Bühlmann et al. 2016). Indeed, the IndVal analysis of our data revealed that dense stands of $A$. viridis were populated by a specialized community of very few species as described earlier by Anthelme et al. (2001, 2003, 2007). These species typically have a high nutrient requirement index suggesting a productive environment with high nutrient availability (Boscutti et al. 2014). Using the observed vegetation transects as a proxy for the temporal development of a given site, we argue that despite similar initial species composition, effects of the locally dominant shrub species supersede environmental influences over time.

As a consequence, in the majority of transects dominated by $A$. viridis, plant species richness steadily decreased with shrub cover. In contrast, many of the transects dominated by $P$. mugo and especially the few transects dominated by Salix sp., R. alpina and P. abies showed the hump-shaped response of species richness to shrub cover often described in literature (Kesting et al. 2015; Pornaro et al. 2013; Soliveres et al. 2014). Moreover, the hump-shape differs between $P$. mugo and other shrub species. In P. mugo transects, plant species richness increases above the value in open pasture by only a single species, namely P. mugo. In dense stands of $P$. mugo, however, plant species richness is only half as large as in open pasture. Other shrub species seem to have other dynamics, but observations are too rare to draw conclusions. Hence, our initial hypothesis $\mathrm{H} 1$ of maximum richness in 
the intermediate transition zone is obviously not generally applicable, as it is evident for $A$. viridis.

Beta-diversity within cover zones shows a hump-shaped form independent of dominant shrub species, in line with hypothesis H1. In A. viridis and $P$. mugo, beta-diversity peaked in zones with scattered bushes, which offer more different habitat niches than open grassland (Villegas et al. 2010). However, while open pastures were only slightly more homogeneous in species composition (i.e. lower betadiversity) than the maximum, dense shrub communities were much more homogeneous. One explanation for the homogeneity is that shrub stands are early successional communities which are dominated by a few plant species, namely the dominant shrub and a few associated species in the understorey. In addition, evenness of plant species composition decreased linearly in all transects, caused by the increasing dominance of a few shrub species.

Environmental factors may also have a crucial influence on vegetation but are difficult to quantify across large areas. One such factor is soil humidity. The water requirement index indicated that transects dominated by $A$. viridis as well as other shrub species were wetter than transects with P. mugo. Rainfall also tended to be smaller on sites dominated by $P$. mugo, but variability was really large. Since no comprehensive spatial information on soil water availability extists, it was difficult to investigate this aspect further.

\section{Challenges of vegetation sampling in pasture-shrub transects}

Sampling vegetation along pasture-shrub transects involves the assessment of plant communities with different structures (Pajunen et al. 2011). Pastures are usually short but dense communities dominated by numerous grasses and small herbaceous plants. Leaf area is concentrated near the soil surface. In contrast, shrub areas consist of two vegetation layers, a shrub layer formed by a limited number of woody species and an understory community of specialized grasses and herbs. Leaf area is thus concentrated at the shrub canopy as well as near the soil surface. Intermediate transition areas between open pastures and dense shrub stands are often heterogeneous because shrubs establish in patches (Duelli 1992), as can be seen from the large heterogeneity in vegetation.

In the subalpine zone, patch size of shrubs varies between a few square decimetres for young individuals to several tens of square meters for groups of individuals. The heterogeneity of the intermediate transition areas complicates placement of representative sampling plots and their subjective placement can bias the results. Moreover, not all shrub effects operate at similar spatial scales. We have overcome the difficulties of heterogeneity, representability and spatial scales by applying a novel sampling protocol. The method is related to Daubemire's transect sampling technique (Stohlgren et al. 1998) and involves two steps: (1) the establishment of cover zones along the transect and (2) the sampling of vegetation in multiple plots at fixed distances. Step 1 ensures representability of the samples for the respective cover zone; Step 2 takes into account heterogeneity and avoids the subjective choice of where to sample. Because of the large heterogeneity, the size of sampling plots needed to be relatively small $(2 \times 2 \mathrm{~m})$. A larger plot size would have levelled variation within the four plots of a cover zone and blurred heterogeneity. Moreover, the small plot size allowed to survey one transect in approximately three days. Our data shows that the observed shrub cover in each sampling plot varied considerably within each cover zone, especially at intermediate values. This means that plant species were observed in the multitude of situations in which they occurred along the transects, be it open pastures, gaps without shrubs, half- or full-shaded spots.

A transparent assessment of the inherent heterogeneity in shrub-pasture transects at multiple spatial scales was possible by analysing the data in a mixed-effects model. It accounts for multiple samples within cover zones along transects and balances the variability within transects as well as within cover zones against variability between and along transects. These methods of sampling and statistical analysis enable unravelling the effects of two relevant levels of shrub cover: plot and zonal cover. The two cover measures differ in their ecological implications: Plot cover has a direct impact on light and nutrient availability for plants, germination success and grazing pressure. Zonal cover affects pollination, seed dispersal, the access of grazing animals in general and, especially in the case of $A$. viridis, the availability of mobile nutrients such as nitrogen. Indeed, plant species richness was more strongly affected by zonal cover in A. viridis than in $P$. mugo. Hence, our data confirmed hypothesis $\mathrm{H} 3$ and demonstrates that both cover types are important determinants of plant species composition depending on the dominant shrub species.

\section{Practical implications for conservation}

The analysis of vegetation indices suggested considerable differences among the three dominant shrub species studied. In $A$. viridis, species richness and evenness declined linearly with increasing cover, whereas beta-diversity peaked at around $35 \%$ and strongly declined in dense stands. A scattered occurrence of $A$. viridis with about $35 \%$ cover increases beta-diversity by $10 \%$, but comes at the price of a species loss of $22 \%$, likely due to the fact that $\mathrm{N}$ enrichment is not restricted to the shrub itself but expands to the surroundings (Bühlmann et al. 2016). Dense A. viridis resulted in $62 \%$ less species and a reduction of beta-diversity of $32 \%$. In P. mugo, species richness was little affected up to a cover 
of $40 \%$ and beta-diversity peaked at around $35 \%$. Hence, a scattered occurrence of $P$. mugo increases beta-diversity without impairing richness. The limited data on other species shows that both diversity measures peak at around 40 to $60 \%$ cover and suggests that a substantial cover of these species promotes species diversity by increasing species richness and beta-diversity ( $+23 \%$ for both).

Our study mainly demonstrates that generalizing effects of shrub encroachment on plant diversity is challenging and potentially misleading. Results of investigations carried out on a single shrub species should only be extrapolated when justifiable. For example, recommendations elaborated from data on dwarf-shrub communities (Koch et al. 2015) or for shrub communities in general (Gómez-Aparicio 2009) cannot be readily translated to communities of other shrub species. The basic message for management is that 'shrub does not equal shrub' and, hence, management decisions need to take into account shrub identity. Species-specific recommendations are necessary for efficient management of shrubencroached areas. This is especially important, where shrubs expand beyond the habitat traditionally associated with their occurrence (Caviezel et al. 2017).

Traditionally, subalpine grasslands were created by a mix of grazing and wood cutting (Schwörer et al. 2014,2015) and it appears reasonable to maintain vegetation composition by the processes that created them (Vera 2000). The dominant shrub species in this study have different palatability to grazers (Cairns and Moen 2004). Leaves of $A$. viridis are relatively well consumed by ruminants (Leng 1997; Papachristou and Papanastasis 1994) and grazing at a sufficient stocking rate is a viable option to keep this species at low cover (Pittarello et al. 2016). In contrast, P. mugo is completely avoided by grazers, similar to Pinus nigra J. F. ARNOLD (Ledgard and Norton 2008) and as common for lowquality forage (Homburger et al. 2015; Pauler et al. 2020). Hence, mechanical interventions are necessary to manage encroachment of $P$. mugo in pastures. This highlights that the dominant shrub species not only determines the effects of encroachment on vegetation but also potential management strategies to maintain a diverse, semi-open landscape.

\section{Conclusions}

Our survey of 24 subalpine pasture-shrub transects in the Swiss Alps showed that the dominant shrub species is a strong predictor for the response of species diversity to shrub encroachment. A. viridis, the most frequent shrub species in the subalpine zone of the Swiss Alps, severely impairs plant species richness already at a low shrub cover and, in dense stands, also beta-diversity. For conservation of plant species diversity it is thus essential to maintain a low cover of this shrub species. Since $A$. viridis leaves are relatively palatable to ruminants, encroachment by $A$. viridis can potentially be controlled by adapted grazers. In contrast, a moderate cover of $P$. mugo and other shrub species is beneficial to plant species richness and beta-diversity. Since especially $P$. mugo is less attractive to grazers, a carefully designed combination of grazing and mechanical intervention is needed to maintain a semi-open arrangement of pasture and scattered shrubs.

Acknowledgements We thank landowners for permitting access to their land and Diane Bürge and her team for the analysis of soil samples. Matthias Suter and two anonymous reviewers provided valuable comments on the manuscript.

Author contributions MKS, AL, TZ, MK and JB conceived and designed the research; TZ, CR and MKS collected the data. MKS, TZ and CMP analysed the data. MKS and TZ wrote the manuscript with input from $\mathrm{AL}, \mathrm{MK}$ and $\mathrm{CMP}$.

Funding The project was financially supported by the Mercator Research Program of the ETH Zurich World Food System Center. Open access funding provided by Agroscope.

\section{Compliance with ethical standards}

Conflict of interest The authors declare no competing interests.

Open Access This article is licensed under a Creative Commons Attribution 4.0 International License, which permits use, sharing, adaptation, distribution and reproduction in any medium or format, as long as you give appropriate credit to the original author(s) and the source, provide a link to the Creative Commons licence, and indicate if changes were made. The images or other third party material in this article are included in the article's Creative Commons licence, unless indicated otherwise in a credit line to the material. If material is not included in the article's Creative Commons licence and your intended use is not permitted by statutory regulation or exceeds the permitted use, you will need to obtain permission directly from the copyright holder. To view a copy of this licence, visit http://creativecommons.org/licenses/by/4.0/.

\section{References}

Anthelme F, Grossi J-L, Brun J-J, Didier L (2001) Consequences of green alder expansion on vegetation changes and arthropod communities removal in the northern French Alps. Forest Ecol Manag 145:57-65. https://doi.org/10.1016/S0378-1127(00)00574-0

Anthelme F, Michalet R, Barbaro L, Brun J-J (2003) Environmental and spatial influences of shrub cover (Alnus viridis DC.) on vegetation diversity at the upper treeline in the inner western Alps. Arct Antarct Alp Res 35:48-55. https://doi.org/10.1657/15230430(2003)035[0048:EASIOS]2.0.CO;2

Anthelme F, Villaret J-C, Brun J-J (2007) Shrub encroachment in the Alps gives rise to the convergence of sub-alpine communities on a regional scale. J Veg Sci 18:355-362. https://doi. org/10.1111/j.1654-1103.2007.tb02547.x

BFS (2013) Die Bodennutzung in der Schweiz, Arealstatistik 2004/2009. Swiss Statistical Office, Berne

Blaum N, Rossmanith E, Popp A, Jeltsch F (2007) Shrub encroachment affects mammalian carnivore abundance and species richness in semiarid rangelands. Acta Oecol 31:86-92. https://doi. org/10.1016/j.actao.2006.10.004 
Boscutti F, Poldini L, Buccheri M (2014) Green alder communities in the Alps: phytosociological variability and ecological features. Plant Biosyst 148:917-934. https://doi.org/10.1080/11263 504.2013.809813

Brändli U-B (2010) Schweizerisches Landesforstinventar: Ergebnisse der dritten Erhebung 2004-2006. Swiss Federal Research Institute WSL, Birmensdorf

Bühlmann T, Körner C, Hiltbrunner E (2016) Shrub expansion of Alnus viridis drives former montane grassland into nitrogen saturation. Ecosystems 19:968-985. https://doi.org/10.1007/s1002 1-016-9979-9

Cairns DM, Moen J (2004) Herbivory influences tree lines. J Ecol 92:1019-1024. https://doi.org/10.1111/j.1365-2745.2004.00945.x

Carnelli AL, Theurillat J-P, Thinon M, Vadi G, Talon B (2004) Past uppermost tree limit in the Central European Alps (Switzerland) based on soil and soil charcoal. Holocene 14:393-405. https://doi. org/10.1191/0959683604h1715rp

Caviezel C, Hunziker M, Kuhn NJ (2017) Green alder encroachment in the European Alps: the need for analyzing the spread of a nativeinvasive species across spatial data. CATENA 159:149-158. https ://doi.org/10.1016/j.catena.2017.08.006

Core Team R (2020) R: a language and environment for statistical computing. R Foundation for Statistical Computing, Vienna

Demaria P, Flisch R, Frossard E, Sinaj S (2005) Exchangeability of phosphate extracted by four chemical methods. J Plant Nutr Soil Sci 168:89-93. https://doi.org/10.1002/jpln.200421463

Díaz S et al (2007) Plant trait responses to grazing-a global synthesis. Glob Chang Biol 13:313-341. https://doi.org/10.111 1/j.1365-2486.2006.01288.x

Dong S et al (2011) Vulnerability of worldwide pastoralism to global changes and interdisciplinary strategies for sustainable pastoralism. Ecol Soc 16:10. https://doi.org/10.5751/ES-04093-160210

Duelli P (1992) Mosaikkonzept und Inseltheorie in der Kulturlandschaft. Verh Gesell Ökologie 21:379-384

Dufrêne M, Legendre P (1997) Species assemblages and indicator species: The need for a flexible asymmetrical approach. Ecol Monogr 67:345. https://doi.org/10.2307/2963459

Ellenberg HH (1988) Vegetation ecology of central Europe. Cambridge University Press

Fournier DA et al (2012) AD Model Builder: using automatic differentiation for statistical inference of highly parameterized complex nonlinear models. Optim Method Softw 27:233-249. https://doi. org/10.1080/10556788.2011.597854

García-Tejero S, Taboada Á, Tárrega R, Salgado JM (2013) Land use changes and ground dwelling beetle conservation in extensive grazing dehesa systems of north-west Spain. Biol Conserv 161:58-66. https://doi.org/10.1016/j.biocon.2013.02.017

Gellrich M, Zimmermann NE (2007) Investigating the regional-scale pattern of agricultural land abandonment in the Swiss mountains: a spatial statistical modelling approach. Landsc Urban Plan 79:65-76. https://doi.org/10.1016/j.landurbplan.2006.03.004

Gómez-Aparicio L (2009) The role of plant interactions in the restoration of degraded ecosystems: a meta-analysis across life-forms and ecosystems. J Ecol 97:1202-1214. https://doi.org/10.111 $1 / \mathrm{j} .1365-2745.2009 .01573 . \mathrm{x}$

Hilpold A et al (2018) Decline of rare and specialist species across multiple taxonomic groups after grassland intensification and abandonment. Biodivers Conserv 27:3729-3744. https://doi. org/10.1007/s10531-019-01773-0

Holtmeier F-K (2009) Mountain timberlines: Ecology, patchiness, and dynamics. Springer, Amsterdam. https://doi. org/10.1007/978-1-4020-9705-8

Homburger H, Lüscher A, Scherer-Lorenzen M, Schneider MK (2015) Patterns of livestock activity on heterogeneous subalpine pastures reveal distinct responses to spatial autocorrelation, environment and management. Movement Ecol 3:35. https://doi.org/10.1186/ s40462-015-0053-6

Howard KSC, Eldridge DJ, Soliveres S (2012) Positive effects of shrubs on plant species diversity do not change along a gradient in grazing pressure in an arid shrubland. Basic Appl Ecol 13:159-168. https://doi.org/10.1016/j.baae.2012.02.008

Huss-Danell K (1997) Actinorhizal symbioses and their $\mathrm{N}_{2}$ fxation. New Phytol 136:375-405. https://doi.org/10.104 6/j.1469-8137.1997.00755.x

Jaccard P (1901) Etude comparative de la distribution florale dans une portion des Alpes et du Jura. Bull Soc Vaudoise Sci Nat 37:547-579

Kaphengst T, Ward D (2008) Effects of habitat structure and shrub encroachment on bird species diversity in arid savanna in Northern Cape province, South Africa. Ostrich 79:133-140. https://doi. org/10.2989/OSTRICH.2008.79.2.2.576

Kesting S, Petersen U, Isselstein J (2015) Humped-back shaped response of plant species richness to increasing shrub encroachment in calcareous grasslands. Community Ecol 16:189-195. https://doi.org/10.1556/168.2015.16.2.6

Knapp AK et al (2008) Shrub encroachment in North American grasslands: shifts in growth form dominance rapidly alters control of ecosystem carbon inputs. Glob Chang Biol 14:615-623. https:// doi.org/10.1111/j.1365-2486.2007.01512.x

Koch B, Edwards PJ, Blanckenhorn WU, Walter T, Hofer G (2015) Shrub encroachment affects the diversity of plants, butterflies, and grasshoppers on two Swiss subalpine pastures. Arct Antarct Alp Res 47:345-357. https://doi.org/10.1657/AAAR0013-093

Komac B, Kéfi S, Nuche P, Escós J, Alados CL (2013) Modeling shrub encroachment in subalpine grasslands under different environmental and management scenarios. J Env Manag 121:160-169. https ://doi.org/10.1016/j.jenvman.2013.01.038

Laiolo P, Dondero F, Ciliento E, Rolando A (2004) Consequences of pastoral abandonment for the structure and diversity of the alpine avifauna. J Appl Ecol 41:294-304. https://doi.org/10.111 1/j.0021-8901.2004.00893.x

Landolt E, Bäumler B (2010) Flora indicativa, 2nd edn. Haupt, Berne

Lauber K, Wagner G (2007) Flora helvetica, 4th edn. Haupt, Berne

Lauber S et al (2013) Zukunft der Schweizer Alpwirtschaft. Swiss Federal Research Institute WSL, Birmensdorf

Ledgard N, Norton D (2008) The impact of browsing on wilding conifers in the South Island high country. NZ J Forestry 52:29-34

Leng RA (1997) Tree foliage in ruminant nutrition. FAO animal production and health paper, vol 139. Food and Agriculture Organization of the United Nations, Rome

Liechti K, Biber JP (2016) Pastoralism in Europe: characteristics and challenges of highland-lowland transhumance. Rev Sci Tech OIE 35:561-575. https://doi.org/10.20506/rst.35.2.2541

Loranger H, Zotz G, Bader MY (2017) Competitor or facilitator? The ambiguous role of alpine grassland for the early establishment of tree seedlings at treeline. Oikos 126:1625-1636. https://doi. org/10.1111/oik.04377

Nakagawa S, Schielzeth H (2012) A general and simple method for obtaining $\mathrm{R}^{2}$ from generalized linear mixed-effects models. Method Ecol Evol 4:133-142. https://doi.org/10.1111/j.2041210x.2012.00261.x

Pajunen AM, Oksanen J, Virtanen R (2011) Impact of shrub canopies on understorey vegetation in western Eurasian tundra. J Veg Sci 22:837-846. https://doi.org/10.1111/j.1654-1103.2011.01285.x

Pajunen A, Virtanen R, Roininen H (2012) Browsing-mediated shrub canopy changes drive composition and species richness in foresttundra ecosystems. Oikos 121:1544-1552. https://doi.org/10.111 1/j.1600-0706.2011.20115.x

Papachristou TG, Papanastasis VP (1994) Forage value of Mediterranean deciduous woody fodder species and its implication to 
management of silvo-pastoral systems for goats. Agroforest Syst 27:269-282. https://doi.org/10.1007/BF00705061

Pauler CM, Isselstein J, Suter M, Berard J, Braunbeck T, Schneider MK (2020) Choosy grazers: Influence of plant traits on forage selection by three cattle breeds. Func Ecol 34:980-992. https:// doi.org/10.1111/1365-2435.13542

Peter M, Gigon A, Edwards P, Lüscher A (2009) Changes over three decades in the floristic composition of nutrient-poor grasslands in the Swiss Alps. Biodivers Conserv 18:547-567. https://doi. org/10.1007/s10531-008-9521-2

Pinheiro JC, Bates DM (2000) Mixed-effects models in S and S-PLUS. Springer, New York

Pittarello M, Probo M, Lonati M, Lombardi G (2016) Restoration of sub-alpine shrub-encroached grasslands through pastoral practices: effects on vegetation structure and botanical composition. Appl Veg Sci 19:381-390. https://doi.org/10.1111/avsc.12222

Pornaro C, Schneider MK, Macolino S (2013) Plant species loss due to forest succession in Alpine pastures depends on site conditions and observation scale. Biol Conserv 161:213-222. https://doi. org/10.1016/j.biocon.2013.02.019

Pornaro C, Schneider MK, Leinauer B, Macolino S (2017) Aboveand belowground patterns in a subalpine grassland-shrub mosaic. Plant Biosyst 151:493-503. https://doi.org/10.1080/11263 504.2016.1187679

Queiroz C, Beilin R, Folke C, Lindborg R (2014) Farmland abandonment: threat or opportunity for biodiversity conservation? A global review. Frontiers Ecol Environ 12:288-296. https://doi. org/10.1890/120348

Ratajczak Z, Nippert JB, Collins SL (2012) Woody encroachment decreases diversity across North American grasslands and savannas. Ecology 93:697-703. https://doi.org/10.1890/11-1199.1

Rejmének M, Rosén E (1992) Influence of colonizing shrubs on species-area relationships in alvar plant communities. J Veg Sci $3: 625-630$

Schwörer C et al (2014) Holocene climate, fire and vegetation dynamics at the treeline in the Northwestern Swiss Alps. Veg Hist Archaeobot 23:479-496. https://doi.org/10.1007/s00334-013-0411-5

Schwörer C, Colombaroli D, Kaltenrieder P, Rey F, Tinner W (2015) Early human impact (5000-3000 BC) affects mountain forest dynamics in the Alps. J Ecol 103:281-295. https://doi. org/10.1111/1365-2745.12354

Soliveres S, Maestre FT, Eldridge DJ, Delgado-Baquerizo M, Quero JL, Bowker MA, Gallardo A (2014) Plant diversity and ecosystem multifunctionality peak at intermediate levels of woody cover in global drylands: woody dominance and ecosystem functioning. Global Ecol Biogeogr 23:1408-1416. https://doi.org/10.1111/ geb. 12215

Stohlgren TJ, Bull KA, Otsuki Y (1998) Comparison of rangeland vegetation sampling techniques in the central grasslands. J Range Manag 51:164-172

Strebel N, Bühler C (2015) Recent shifts in plant species suggest opposing land-use changes in alpine pastures. Alp Botany 125:19. https://doi.org/10.1007/s00035-015-0145-3

Tasser E, Tappeiner U (2002) Impact of land use changes on mountain vegetation. Appl Veg Sci 5:173-184. https://doi.org/10.1111/ j.1654-109X.2002.tb00547.x

Tasser E, Schirpke U, Zoderer BM, Tappeiner U (2020) Towards an integrative assessment of land-use type values from the perspective of ecosystem services. Ecosyst Serv 42:101082. https://doi. org/10.1016/j.ecoser.2020.101082

Teleki B, Sonkoly J, Erdős L, Tóthmérész B, Prommer M, Török P (2020) High resistance of plant biodiversity to moderate native woody encroachment in loess steppe grassland fragments. Appl Veg Sci 23:175-184. https://doi.org/10.1111/avsc.12474

Vera FWM (2000) Grazing ecology and forest history. CABI publishing, Wallingford

Villegas JC, Breshears DD, Zou CB, Royer PD (2010) Seasonally pulsed heterogeneity in microclimate: phenology and cover effects along deciduous grassland-forest continuum. Vadose Zone J 9:537-547. https://doi.org/10.2136/vzj2009.0032

Wild J, Winkler E (2008) Krummholz and grassland coexistence above the forest-line in the Krkonoše Mountains: grid-based model of shrub dynamics. Ecol Model 213:293-307. https://doi. org/10.1016/j.ecolmodel.2007.12.013

Wilson JB, Peet RK, Dengler J, Pärtel M (2012) Plant species richness: the world records. J Veg Sci 23:796-802. https://doi.org/10.111 $1 /$ j.1654-1103.2012.01400.x

Publisher's Note Springer Nature remains neutral with regard to jurisdictional claims in published maps and institutional affiliations. 